DOI: $10.19195 / 2300-7729.36 .1$

\author{
TOMASZ BIERKOWSKI \\ Akademia Sztuk Pięknych w Katowicach \\ EWA REPUCHO \\ Uniwersytet Wrocławski
}

\title{
Co mówią okładki? O jakości komunikatów wizualnych współczesnych edycji wydawanych przez bibliologów i dla bibliologów
}

\section{Wprowadzenie}

Publikacje naukowe stanowią istotny segment polskiego rynku książki około $34 \%$ całej rocznej produkcji wydawniczej ${ }^{1}$. Niemal połowa wymienionych pozycji ukazuje się nakładem instytucji naukowych, przede wszystkim szkół wyższych, jedną czwartą wydają profesjonalne komercyjne oficyny, a resztę różnego rodzaju fundacje, instytucje kultury i stowarzyszenia ${ }^{2}$. Rynek ten jest więc mocno rozdrobniony i nie zawsze książki wydają profesjonaliści. Ponadto wielką bolączkę rynku stanowi jego niedoinwestowanie. Segment nie należy bowiem do szczególnie dochodowych ${ }^{3}$, a sytuacja pogorszyła się jeszcze w 2012 roku, kiedy Ministerstwo Nauki i Szkolnictwa Wyższego zakończyło program przyznawania dotacji do podręczników akademickich. Łukasz Gołębiewski i Paweł Waszczyk podkreślają, że w obliczu wielu trudności, jakie napotyka rynek książki naukowej $^{4}$, publikacje nie są wydawane tak jak powinny. Wydawcy, borykając

${ }^{1}$ Ruch wydawniczy w liczbach 2016. Książki, t. 63, Warszawa 2017, s. 13, http://ksiegarnia.bn.org. pl/pdf/Ruch\%20wydawniczy\%20w\%20liczbach\%2061_2015\%20ksiazki.pdf [dostęp: 31.05.2017].

2 Ibidem.

3 P. Dobrołęcki, Podręczniki bez dotacji, „Forum Książki” 2013, nr 1, (01), https://forumakademickie.pl/fk/2013/01/podreczniki-bez-dotacji/ [dostęp: 31.05.2017].

4 Świadczą o tym chociażby liczne artykuły poświęcone kondycji książki naukowej i akademickiej: P. Dobrołęcki, Najwięcej tytułów i niskie płace. Książa akademicka 2009/2010, „Biblioteka Analiz” 2010, nr 22, s. 15-17; P. Kieraciński, Podręcznik w kryzysie, „Forum Książki” 2009, nr 1, s. 11; A. Chrzanowski, Dotacje na podręczniki. Wydawcy akademiccy w Ministerstwie Nauki 
się z ograniczeniami finansowymi, próbują ciąć koszty i ograniczają etaty niemal we wszystkich działach wydawnictwa, zwalniają specjalistów z wieloletnim doświadczeniem i zastępują mniej wykwalifikowanymi, a jednocześnie tańszymi pracownikami. W efekcie obniża się nawet jakość opracowania redakcyjnego publikowanych dzieł, nie wspominając już o korekcie ${ }^{5}$. Brakuje także odpowiedniego projektu graficznego ${ }^{6}$. Opracowanie typograficzne jest bowiem tym elementem, z którego — ze względu na oszczędności — rezygnuje się w pierwszej kolejności. Bardzo trafnie podsumowuje tę sytuację Sylwia Breczko, kierownik Wydawnictwa Biblioteki Narodowej, pytając, jak przygotowana w taki sposób publikacja naukowa ma się do akademickiego prestiżu, który za jej pomocą chce się zdobyć? ${ }^{7}$

Książka naukowa ma rozpowszechniać wiedzę, idee, wyniki badań, a więc skutecznie dystrybuować informacje. Aby jednak publikacja mogła spełnić swoje funkcje informacyjne, musi być przygotowana z najwyższą starannością nie tylko pod względem treści, lecz także formy. Badania z zakresu czytelności druku ${ }^{8}$ jednoznacznie wskazują, że układ typograficzny edycji jest niezwykle istotnym, wręcz kluczowym elementem całego przekazu. We współczesnym świecie, nastawionym tak wyraźnie na odbiór bodźców wizualnych, forma edycji nie pozostaje bez znaczenia na decyzje czytelnika, lecz wpływa na użyteczność i funkcjonalność komunikatów. Niemiecki typograf Wolfgang Weingart, znany z eksperymentalnych, pełnych ekspresji prac przełamujących zasady klasycznej „,szwajcarskiej typografii”, uważa, że dziś, gdy społeczeństwo jest tak mocno uzależnione od bodźców wizualnych, sama czytelność tekstu nie wystarczy. Cóż z tego, że tekst jest czytelny, skoro nikt nie będzie chciał go przeczytać? ${ }^{9}$ — twierdzi Weingart. W kontekście formy typograficznej współczesnych edycji naukowych można sparafrazować te słowa w następujący sposób — cóż

i Szkolnictwa Wyższego, „Biblioteka Analiz” 2008, nr 27, s. 21; Z. Saloni, Jak wydawatem skrypt, „Forum Akademickie” 2007, r. 14, nr 9, s. 48-50; P. Waszczyk, Nie ma złych metod. Promocja podręczników akademickich, „Biblioteka Analiz” 2006, nr 22, s. 24-25; M. Czubaj, Kserówka, „Polityka” 2006, nr 7, s. 88-89; W. Karwacki, Mizeria czyli o książe akademickiej, „Notes Wydawniczy" 2001, nr 3-4, s. 23-24; J. Walewska, Raport o stanie książki akademickiej i naukowej, Warszawa 2001; J. Walewska, Uczelnia i spółka z o.o., „Notes Wydawniczy” 1999, nr 2, s. 16-20.

5 Ł. Gołębiewski, P. Waszczyk, Rynek książki w Polsce 2015: wydawnictwa, Warszawa 2015, s. 80 .

6 Ibidem, s. 33.

7 S. Breczko, Ksiązka naukowa - między środowiskiem akademickim a branża wydawnicza, „Nauka i Szkolnictwo Wyższe” 2016, nr 2 (48), s. 113, http://pressto.amu.edu.pl/index.php/ nsw/article/view/7632 [dostęp: 31.05.2017].

8 B. Zachrisson, Studia nad czytelnościa druku, Warszawa 1970; E. Stopa-Pielesz, Estetyka w typografii wobec postulatu czytelności, Kraków 2009; T. Bierkowski, Jak korzystać z wyników badań w tworzeniu komunikatów typograficznych, „Toruńskie Studia Bibliologiczne” 2015, nr 1 (14), s. 73-86.

9 K. Chi-Hang Tam, Typograficzny pejzaż Wolfganga Weingarta, „2+3D” 2003, nr 6, s. 1, http:// www.2plus3d.pl/artykuly/typograficzny-pejzaz-wolfganga-weingarta/strona:1 [dostęp: 3.03.2017]. 
z tego, że tekst da się przeczytać, skoro forma zewnętrzna książki zniechęci potencjalnego czytelnika, który nie będzie chciał jej wziąć do ręki? ${ }^{10}$

Układ graficzny współczesnej książki naukowej jest często marginalizowany, podkreśla się znaczenie treści, bagatelizując wartość formy. Analizując cykl powstawania publikacji naukowych — od prac autora aż po działania wydawnicze i poligraficzne - niejednokrotnie wręcz uderza rozdźwięk między wysokim stopniem zaangażowania autorów, redaktorów merytorycznych, tłumaczy itp. a lekceważeniem samego układu graficznego publikacji. Książki bardzo często wydawane są sztampowo, według jednego wzoru.

Problem ten dotyczy znacznej większości współczesnych publikacji naukowych — a więc także książek pisanych przez bibliologów i dla bibliologów — edycji wydawanych zarówno przez profesjonalne wydawnictwa naukowe, jak i ukazujących się nakładem instytucji naukowych, bibliotek, różnego rodzaju fundacji oraz stowarzyszeń. Tymczasem może właśnie z tego środowiska, jako szczególnie predysponowanego, rozumiejącego zagadnienia szeroko pojętej książki funkcjonalnej, powinien wyjść sygnał do zmiany. Na znaczenie układu typograficznego książki bowiem zwracali już uwagę czołowi polscy bibliolodzy: Jan Muszkowski czy Karol Głombiowski ${ }^{11}$. Ten ostatni podkreślał: ,[m]aterializacja graficzna tekstu implikuje [...] także przekazywanie go odbiorcy - indywidualnemu i zbiorowemu"12. Głombiowski wskazywał na znaczenie użytkowego, czytelniczego charakteru typografii książki, kształtowania jej w taki sposób, ,aby czytelnik z łatwością i z estetycznym zadowoleniem mógł odbierać prezentowany przez wydawcę tekst"13. Celem niniejszego artykułu jest zatem zwrócenie uwagi bibliologów na niską jakość typograficzną publikacji, które ukazują się z ich inicjatywy, a także uświadomienie badaczom, że forma, w jakiej ukazują się teksty, ma istotny wpływ na ich zrozumienie.

$\mathrm{W}$ artykule podjęto próbę obiektywnej oceny współczesnych polskich edycji z zakresu bibliologii pod względem ich formy typograficznej. Wnioski zostały poprzedzone wnikliwą analizą typograficzną około 400 pozycji z dziedziny bibliologii i informatologii, wydanych w Polsce w ciągu ostatnich 10 lat, a więc $\mathrm{w}$ okresie, który przyniósł na polskim rynku wydawniczym widoczny skok w poprawie jakości graficznej i typograficznej edycji. Wnioski zaprezentowano na przykładzie okładek współczesnych edycji bibliologicznych, skupiając się na jakości komunikacyjnej na poziomie semantycznym. Okładki są bowiem pierwszym komunikatem skierowanym do czytelnika, a poza tym niezwykle

10 Zapewne w mniejszym stopniu dotyczy to zmotywowanego pracownika naukowego, ale doktorant czy student nie będzie już tak zdeterminowany.

11 E. Repucho, Typografia w przestrzeni cyfrowej jako przedmiot badań bibliologicznych, „Acta Poligraphica” 2016, nr 7, s. 37-48.

12 K. Głombiowski, Teoria i metodologia nauki o książe, Gdańsk 1985, s. 11.

13 K. Głombiowski, Ksiązka w procesie komunikacji społecznej, Wrocław-Warszawa-Kraków 1980, s. 46. 
obrazowym materiałem, przemawiającym na różnych płaszczyznach. Jednocześnie — aż nazbyt często - są zapowiedzią jakości opracowania całej pozycji ${ }^{14}$.

\section{Funkcje komunikacyjne okładki}

„Nie ocenia się książki po okładce”, „nie szata zdobi człowieka” — prawdopodobnie nie ma bardziej mylnych określeń w odniesieniu do pierwszej, powierzchownej, ale istotnej z punktu widzenia dalszej relacji, oceny przedmiotu lub osoby. Psychologowie stworzyli setki prac na temat roli wyglądu i zachowania dla osób, na przykład starających się o pracę, które chcą wzbudzić zainteresowanie, wywrzeć odpowiednie - właściwe danemu kontekstowi miejsca i celu wrażenie, wzbudzić zaufanie, sympatię bądź też kojarzyć się z profesjonalizmem ${ }^{15}$. Podobnie dzieje się z postrzeganiem przedmiotów, których problematyce projektowania również poświęcono wiele ważnych opracowań ${ }^{16}$. Książka jest obiektem trójwymiarowym i w pewnym zakresie komunikuje nie tylko wizualnie, lecz także namacalnie, o czym część typografów i wydawców zapomina ${ }^{17}$. Biorąc książkę do ręki, potencjalny czytelnik pozyskuje szacunkowe informacje dotyczące jej wagi, wymiarów, a na podstawie dotyku poznaje rodzaj użytego papieru, jego gramaturę oraz rodzaj oprawy. W efekcie analizy cech fizycznych powstają pierwsze wyobrażenia i ocena dzieła. Wertując książkę i przeglądając ją, przyszły czytelnik jest w stanie dowiedzieć się więcej na temat jej treści, objętości, struktury czy gatunku, niż z lektury samego tytułu. Ponadto krótki rzut oka na rozkładówkę dostarcza użytkownikowi informacji, z jakim rodzajem komunikatu typograficznego ma do czynienia, na przykład z beletrystyką, poezją czy podręcznikiem.

Zanim jednak książka zostanie wzięta do ręki, a następnie zidentyfikowana i oceniona w opisany sposób, jej okładka musi zaintrygować potencjalnego czy-

$14 \mathrm{~W}$ trakcie przygotowań jest całościowe opracowanie poświęcone typografii książki naukowej.

15 „Czy chcemy się do tego przyznać, czy nie, wszyscy przejmujemy się wizerunkiem, jaki prezentujemy reszcie świata — lub nawet wyobrażeniem o sobie. [...] nawet ludzie, którzy zapewniają o kompletnym braku zainteresowania tym, jak są postrzegani, ubierając się w najprostsze lub najwygodniejsze ubrania, unikając kupowania nowych przedmiotów do momentu, aż te, których używają, przestaną działać — składają deklarację o sobie i rzeczach, o które się troszczą. To wszystko są właściwości refleksyjnego przetwarzania informacji” — por. D.A. Norman, Wzornictwo i emocje, Warszawa 2015, s. 88.

16 Na przykład: D.A. Norman, Wzornictwo...; D.A. Norman, The Design of Everyday Things, New York 2013.

17 „Fizyczny dotyk i odczucie mogą powodować ogromną różnicę w odbiorze jakiegoś wzoru [...]. Obiekty fizyczne [a są nimi również książki - T.B., E.R.] mają wagę, fakturę i powierzchnię. We wzornictwie określa się te cechy mianem namacalności. Odczucia fizyczne mają znaczenie. W końcu jesteśmy istotami żywymi, mamy materialne ciała, ręce i nogi. Ogromną część mózgu zajmuje system sensoryczny, który nieustannie bada środowisko i wchodzi z nim w interakcje" - por. D.A. Norman, Wzornictwo..., s. 85-56. 
telnika, wzbudzić jego zainteresowanie. W pełni świadomie dla odbiorcy dzieje się to za pośrednictwem umieszczonego na okładce tekstu (treść tytułu, nazwisko autora) czy też obrazu (treść ilustracji i/lub jej forma).

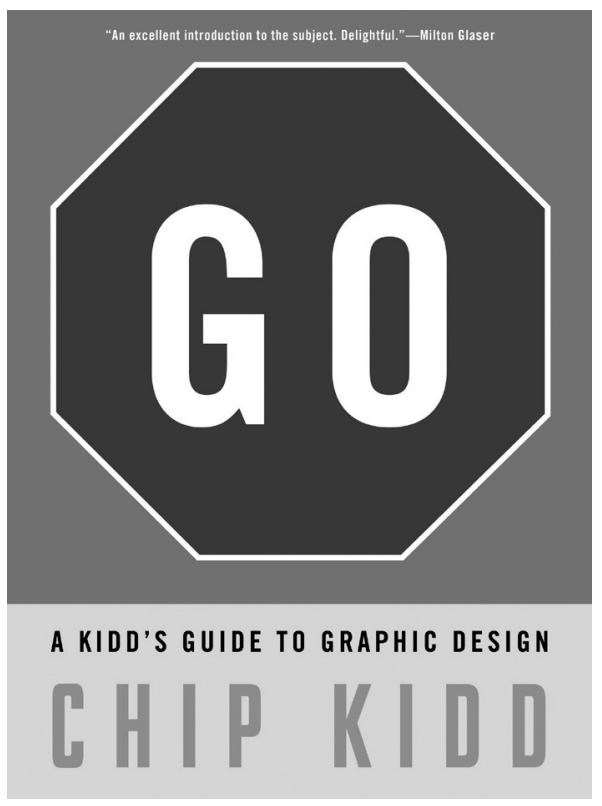

Ilustracja 1. Chip Kidd, GO: A Kidd's Guide to Graphic Design, New York 2013*

Warto pamiętać, że każdy komunikat wizualny — w tym okładka — jest odbierany całościowo. W jego percepcji ma zastosowanie zasada synergii - treści tekstu i obrazu tworzą wzajemne relacje, dopełniają się i ostatecznie wysyłają komunikat o treści książki do odbiorcy (a przynajmniej budzą konotacje, które mogą, ale też nie muszą, być zbieżne z zawartością publikacji i przez to generować wysoką jakość przekazu). „Podstawą precyzji w komunikacji jest równoległe traktowanie formy i treści, a nawet więcej — traktowanie ich jako nierozdzielnej całości. [...] skuteczność jest tym, co trzeba widzieć poza intencjami i emocjami"18. Odbiorca okładki nie jest $\mathrm{w}$ stanie odseparować treści tekstu i ilustracji, jeśli te $\mathrm{z}$ sobą sąsiadują, ponieważ treść jednego i drugiego wzajemnie determinuje recepcję, a następnie skojarzenia. Zatem to okładka książki, między innymi dzięki swojej reprezentatywnej funkcji, jest „portalem”, który powinien kierować potencjalnego czytelnika do jej treści. Powiedzenie, że okładka „sprzedaje” książkę, jest ze wszech miar prawdziwe i nie należy rozumieć go tylko literalnie, lecz także metaforycznie; w odniesieniu do wszystkich czynników wizualno-znaczeniowych i emocjonalnych, które mają wzmocnić przekaz zawarty w tytule, pobudzić zainteresowanie oraz

\footnotetext{
* Wszystkie fotografie pochodzą ze zbiorów własnych Tomasza Bierkowskiego.

18 C. Bielecki, Głowa. Instrukcja użytkowania, Warszawa 2016, s. 93.
} 
zachęcić potencjalnego czytelnika do sięgnięcia po książkę. Błędne jest przekonanie, iż jakość projektu edycji jest wtórna w kontekście książki naukowej (jaki inaczej sens miałoby publikowanie czegokolwiek w wersji innej, niż wydruk pliku z edytora tekstu?).

Niewątpliwie okładka opracowania naukowego pełni nieco inną rolę niż wydania komercyjnego, nie zmienia to jednak faktu, że ten autonomiczny element wyposażenia edytorskiego książki musi być zawsze użyteczny ${ }^{19}$. Poza tym mechanizmy percepcji pozostają te same.

\section{Jakość komunikacyjna okładek książek bibliologicznych}

Wraz z przemianą ustrojową, jaka miała miejsce w Polsce po 1989 roku, zaostrzyła się krytyka wszelkich działań komercyjnych związanych z kulturą czy nauką. Choć krytyka ta bywa w niektórych wypadkach uzasadniona, to jednak rodzi też niebezpieczne samozadowolenie, że to, co nieprzeznaczone na sprzedaż jest — z definicji — bardziej wartościowe, fundamentalnie lepsze. Analiza jakości typograficznej książek wydawanych przez współczesne polskie komercyjne wydawnictwa dostarcza jednak przeciwnych dowodów. To właśnie wśród książek komercyjnych widoczne jest powszechne podniesienie poziomu wydawanych dzieł, w tym projektów okładek, w odróżnieniu od publikacji naukowych, które nadal wyglądają, jak gdyby ich wydawcy nie znali dobrych projektantów czy odmiennych — od opatrzonych przez ostatnie 25 lat — rozwiązań edytorskich.

Niewątpliwie każdy projekt okładki to niełatwe i odpowiedzialne zadanie. Ze względu na złożony charakter opracowań naukowych, a szczególnie z powodu wielowątkowości wydań zbiorowych, redaktorzy i autorzy stają przed koniecznością ogólnego i — jednocześnie - precyzyjnego ujęcia problematyki dzieła w tytule; z tego powodu tytuły często mają metaforyczny charakter. W takiej sytuacji stworzenie dobrego projektu okładki, a szczególnie takiej, w której chce się wykorzystać obraz, poza samą treścią tytułu, stanowi niezwykle trudne zadanie. Dlatego też warto zaangażować do tego celu profesjonalnego projektanta i zaprosić go do ścisłej współpracy z zespołem redakcyjnym.

19 Istnieje zasadnicza różnica między pojęciami: „funkcjonalny” i „użyteczny”. Ten ostatni termin jest złożonym zagadnieniem, albowiem produkt spełniający swoje funkcjonalne założenia, wcale nie musi być jednocześnie użyteczny, np. ulotka dołączona do opakowania kropli do oczu, zawierająca informacje między innymi na temat efektów ubocznych, dawkowania czy składu, spełnia swoją funkcję informacyjną, a zatem jest funkcjonalna, jeśli jednak będzie zaprojektowana w sposób niedbały, a środki i parametry typograficzne nie będą ułatwiały czytelności odbiorcy $\mathrm{z}$ dysfunkcją lub chorobą oczu, to o takiej ulotce $\mathrm{w}$ żadnym wypadku nie można powiedzieć, że jest użyteczna. 
Problem ten jest doskonale widoczny w przypadku książek z zakresu bibliologii i informatologii. Wydawałoby się, że banalne stwierdzenie mówiące, iż projekt okładki powinien bezwzględnie odzwierciedlać treść książki, nie powinno znaleźć się w niniejszym opracowaniu, jednak analizując wydawane w ostatnich latach publikacje bibliologiczne, dostrzega się poważne trudności z jakością komunikacyjną ich okładek. Przede wszystkim zwraca uwagę powtarzalność zastosowanych motywów symbolicznych, które — z założenia - mają na celu przekazanie jak najwięcej o zawartości publikacji oraz wzmocnienie przekazu treści dzieła. Niestety, są one najczęściej wykorzystywane przez projektantów okładek niezależnie od sensu tytułu. Stale obecne i powtarzające się motywy to książki, zapełnione nimi półki i regały, klawiatury, budynki oraz wnętrza bibliotek. W wielu wypadkach zostały zastosowane nieadekwatnie do treści, przez co straciły swoją siłę komunikacyjną (Ilustracje 2-5).

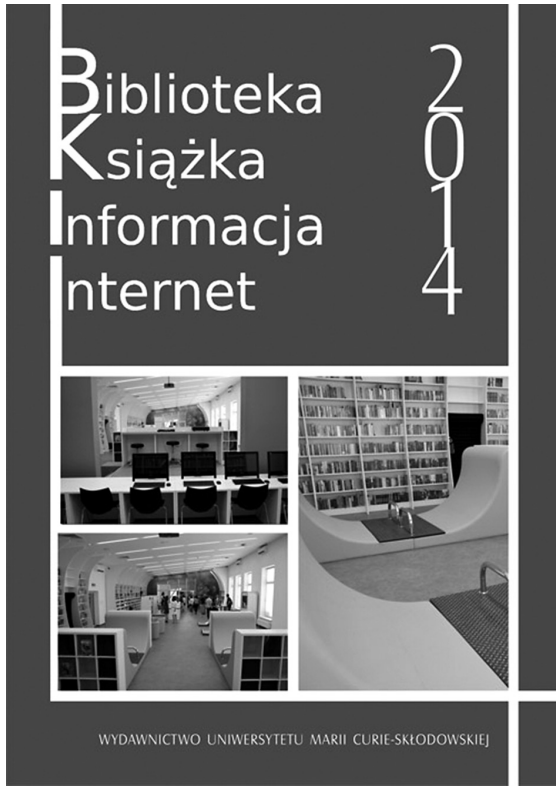

Ilustracja 2. Biblioteka. Ksiażka. Informacja. Internet 2014, Lublin 2014

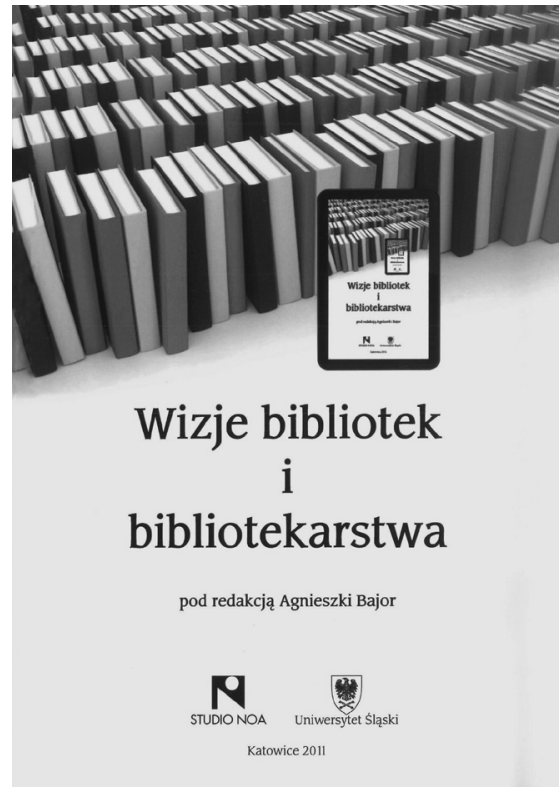

Ilustracja 3. Wizje bibliotek i bibliotekarstwa, Katowice 2012 


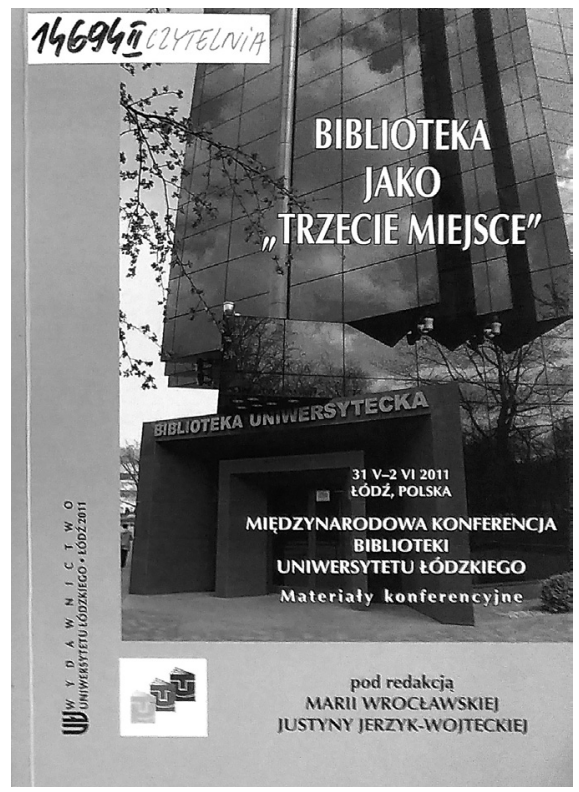

Ilustracja 4. Biblioteka jako ,trzecie miejsce". Materiaty konferencyjne, Łódź 2011

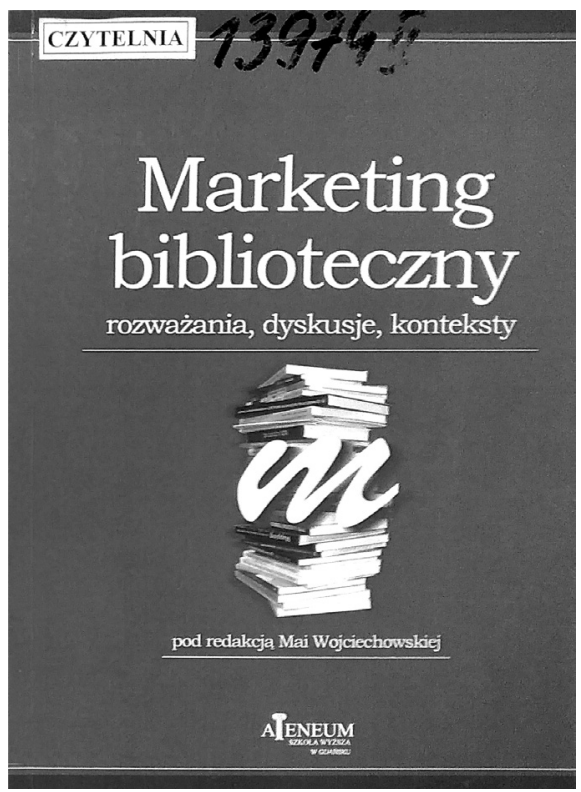

Ilustracja 5. Marketing biblioteczny.

Rozważania, dyskusje, konteksty, Gdańsk 2007

Bardzo wyraźna jest pewnego rodzaju maniera w posługiwaniu się stereotypami (książka, budynek; rzadziej — chmura tagów, klawiatura), która spowodowała, że okładki książek bibliologicznych stały się znaczeniowo transparentne, niedostrzegalne niczym powietrze, którym oddychamy. Poprzez złe decyzje projektowe co do zawartości, jak i formy okładek ich funkcja została sprowadzona wyłącznie do ochrony bloku książki. Jest to szczególnie uderzające, kiedy porówna się z sobą kilkanaście różnych tematycznie opracowań bibliologicznych. Ktoś mógłby stwierdzić, że jest to pewien kanon, określona, a zatem z definicji czytelna dla odbiorcy konwencja. Konwencja ta nie polega jednak na reprezentowaniu różnorodnych tematów publikacji przez te same, powtarzające się motywy. Takie rozwiązania są z powodzeniem wykorzystywane na przykład w wypadku projektowania okładek książek biograficznych. Portret bohatera to niemal stały i obowiązkowy element okładki. Jednak tutaj projektanci w bardzo różnorodny sposób posługują się tym obrazem, a w konsekwencji — budują określone relacje tekst-obraz na poziomie semantycznym lub/i czysto formalnym, graficznym. Wydaje się, że stosowanie tego typu rozwiązań nie jest konieczne w projektach okładek publikacji naukowych, a jeśli nawet zaistniałaby taka potrzeba, to kodem znaczeniowym należałoby posługiwać się w sposób bardziej kreatywny, dążąc do uzyskania większej rozpoznawalności, a także efektu wyjątkowości. Warto posłużyć się tu jako przykładem okładką polskiego wydania autobiografii Josepha Antona autorstwa Salmana Rushdiego, która ope- 
ruje nieuzasadnioną w odniesieniu do treści konwencją, a przez to ujawnia czytelnikowi tajemnicę i sens opowieści już na samym jej początku. Okładki wydań zachodnich są znacznie bardziej intrygujące, nawet do tego stopnia, że nie wiemy czy autorem jest Joseph Anton, czy też Salman Rushdie (Ilustracje 6-8).

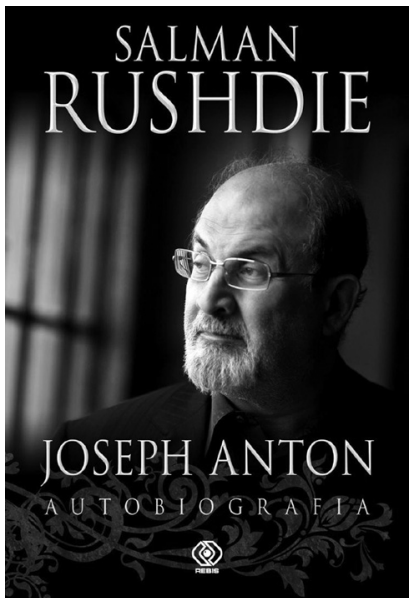

Ilustracja 6. Salman Rushide, Joseph Anton - autobiografia, Poznań 2012

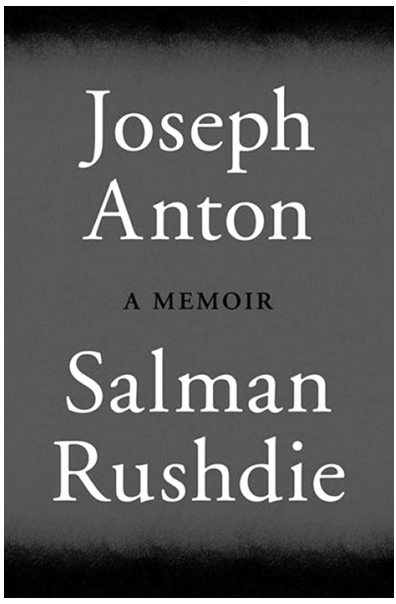

Ilustracja 7. Salman Rushide, Joseph Anton a memoir, New York 2012

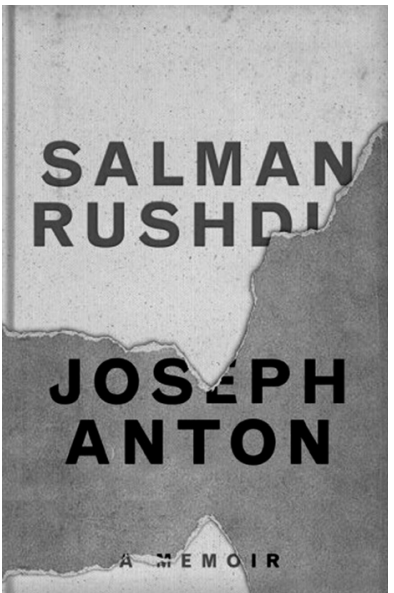

Ilustracja 8. Salman Rushide, Joseph Anton a memoir, London 2012

Polskie wydanie „Josepha Antona” S. Rushdiego operuje nieuzasadnioną w odniesieniu do treści — konwencją, a przez to - ujawnia czytelnikowi tajemnicę, sens opowieści już na samym początku. Okładki wydań zachodnich intrygują do tego stopnia, że nie wiemy czy autorem jest J. Anton, czy też S. Rushdie.

\section{Neutralność, dosłowność, nieprzystawalność}

Przeanalizowane pod względem użytkowym okładki publikacji bibliologicznych można podzielić na dwie grupy. W pierwszej zrezygnowano z ilustracji na rzecz samego tekstu. Okładki te pod względem semantycznym są niemal abstrakcyjne, nieoczywiste, dzięki czemu dają odbiorcy szerokie pole do interpretacji. Nie zawsze jednak rozwiązania tego typu wspomagają przekaz, czasami mogą przywodzić zbyt odległe skojarzenia.

$\mathrm{W}$ drugiej grupie połączono tekst $\mathrm{z}$ obrazem. Okładki te zdecydowanie więcej i szybciej mogą przekazać odbiorcy poprzez wzajemne relacje znaczeniowe. Są przez to dużo trudniejsze do zaprojektowania, ponieważ łatwiej o popełnienie 
błędu przez projektanta i/lub redaktora naukowego. Treści i konotacji tego typu jest dużo więcej, ale nie oznacza to, że są one zawsze trafne ${ }^{20}$.

Zarówno w pierwszej, jak i drugiej grupie projektów dominują — niestety mniej lub bardziej błędne rozwiązania, które można sklasyfikować następująco:

1. neutralność — zastosowany język wizualny nie przeszkadza, ale i specjalnie nie pomaga w przybliżeniu znaczenia lub sensu tytułu; pod względem formalnym okładka również nie zwraca uwagi i nie działa przyciągająco. Okładki zaprojektowane w ten sposób nie wnoszą niczego, co mogłoby intrygować potencjalnego czytelnika i zachęcać go do sięgnięcia po książkę. Na zainteresowanie publikacją i jej atrakcyjność „pracuje” wyłącznie treść tytułu bądź nazwisko autora (Ilustracja 9).

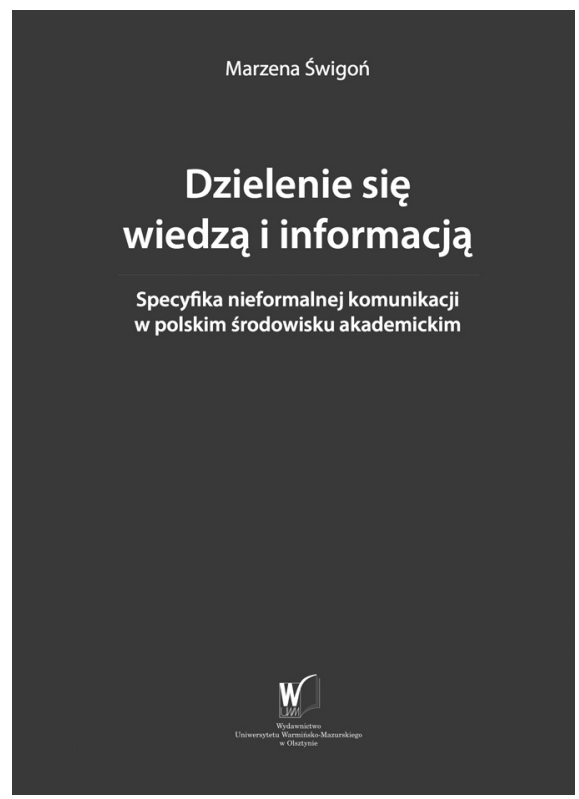

Ilustracja 9. M. Świgoń, Dzielenie się wiedza i informacją: Specyfika nieformalnej komunikacji w polskim środowisku akademickim, Olsztyn 2015

2. dosłowność — zestawione z tytułami obrazy, niezależnie od tego, czy są nimi fotografie, czy rysunki, oraz tego w jakim stopniu ich forma jest uproszczona, ilustrują dosłownie treść zapisu. Przekazy tekstowy i obrazowy nie dopełniają się, tylko w różnych formach powtarzają te same treści. Innymi słowy, zawartość tytułu jest literalnie lub prawie literalnie przekładana na zapis obrazowy, na przykład jeśli w tytule mowa o bibliotece, to zestawia się go z budynkiem biblioteki lub jej wnętrzem. Zbliżony do opisanego sposób myślenia to dosłowne ilustrowanie metafory - jeśli opracowanie traktuje o bibliotece cyfrowej, to półki z książkami

20 O semantycznej relacji obraz-tekst pisze T. Zbierski, Semiotyka książki, Wrocław 1978, s. 15. Z kolei o relacji graficznej między obrazem a tekstem wypowiada się E. Ruder, Typography, Niederteufen 1977, s. 262-263. 
są umieszczane na ekranie komputera ${ }^{21}$. Z tych powodów okładka staje się intelektualnie nienachalna, czasem groteskowa i podobnie jak w przypadku opisanych w punkcie pierwszym - okładek, które cechuje neutralność, w żaden sposób nie „sprzedają" one dzieła. Trzeba jednak nadmienić, że zwielokrotnienie tej samej treści obrazem i tekstem (tak zwana relacja „obraz w płaszczyźnie tekstu”) stanowi sprawdzoną metodą komunikowania w wypadku niektórych komunikatów infograficznych lub instrukcji, wszędzie tam, gdzie przekaz tekstowy jest na tyle skomplikowany i trudny do zrozumienia, że wymaga wsparcia precyzyjną, wiernie prezentującą opis ilustracją ${ }^{22}$ (Ilustracje 10-11).

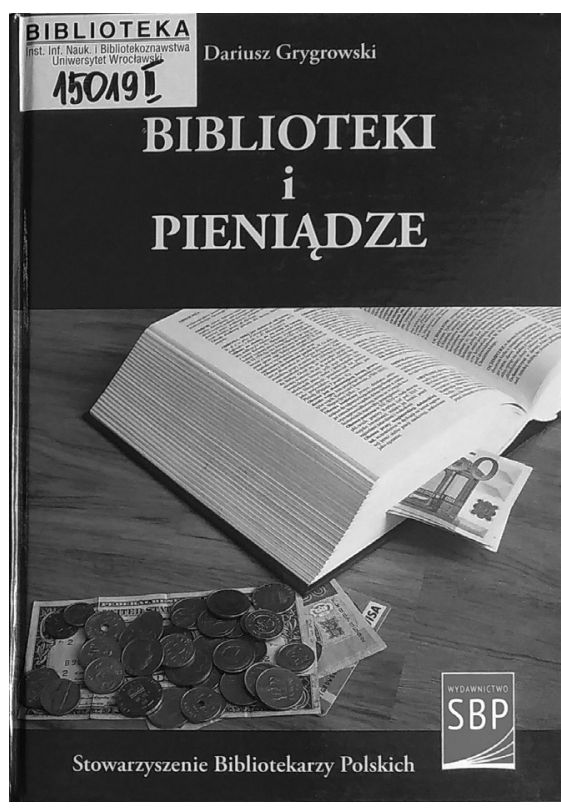

Ilustracja 10. D. Grygrowski, Biblioteki i pieniadze, Warszawa 2015

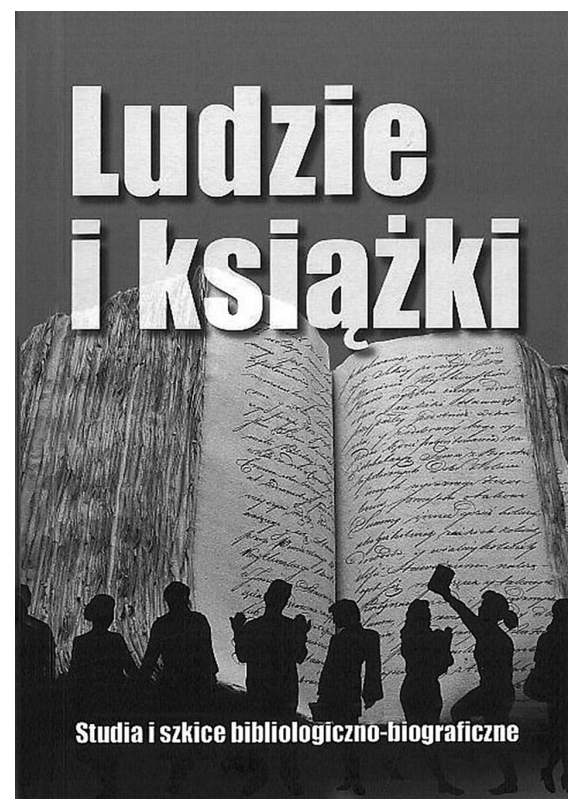

Ilustracja 11. Ludzie i ksiązki. Studia i szkice bibliograficzno-biograficzne, Łódź 2011

3. nieprzystawalność - okładki charakteryzują się zbyt dużą odległością skojarzeń (Ilustracje 12-13).

${ }^{21}$ Chyba najbardziej znanym i budzącym kontrowersje w Polsce lat 90. przykładem literalnego ilustrowania metafory jest plakat A. Pągowskiego „Papierosy są do dupy”. Przedstawiono na nim palącego papierosa mężczyznę, który w miejscu twarzy ma pośladki. Niestety ten sposób komunikowania obrazem w żaden sposób nie ułatwia zrozumienia sensu przesłania, przede wszystkim nie dostarcza żadnej nowej informacji szkodliwości palenia, poza komunałem mówiącym, iż „papierosy są złe”. Plakat może też być odebrany jako niesmaczny i jest on daleki od mistrzowskiego operowania metaforą na przykład przez przedstawicieli tak zwanej polskiej szkoły plakatu.

22 Por. J. Trzynadlowski, Autor, dzieło, wydawca, Wrocław 1979, s. 124. 


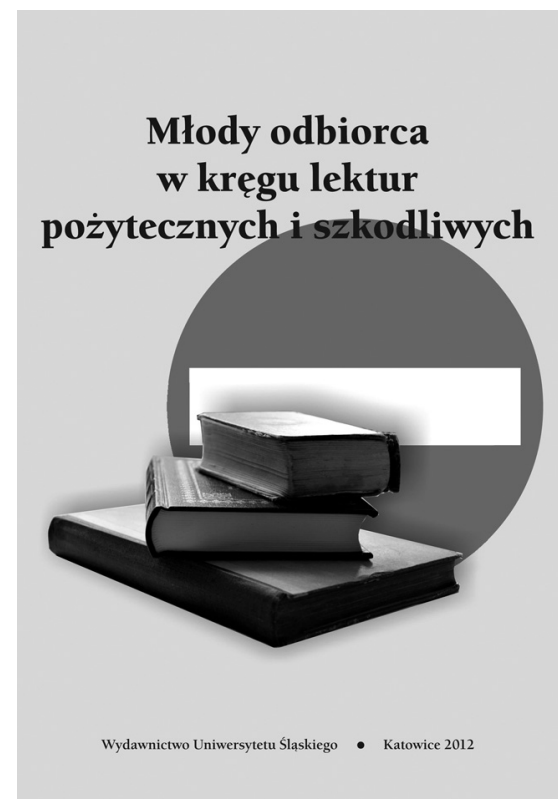

Ilustracja 12. Młody odbiorca w kręgu lektur pożytecznych i szkodliwych, Katowice 2014

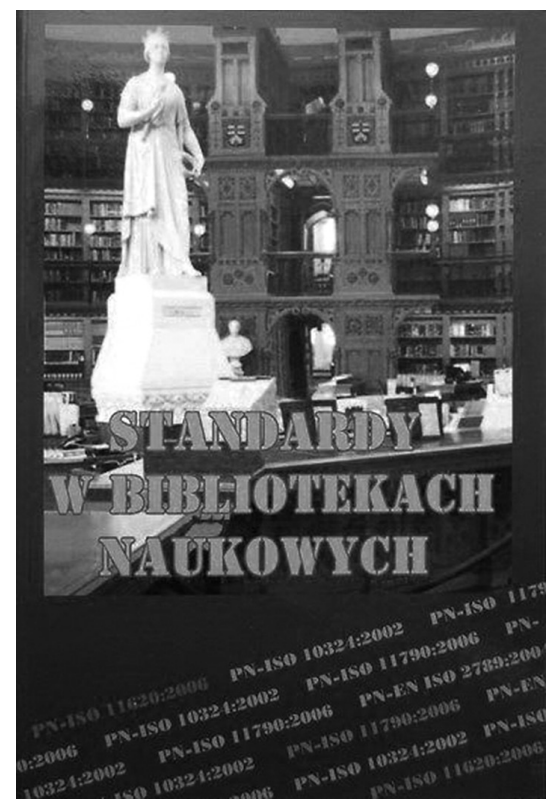

Ilustracja 13. Standardy w bibliotekach naukowych, Warszawa 2007

Poza problemami natury semantycznej okładek publikacji bibliologicznych pojawiają się kłopoty z organizacją hierarchii informacji, błędami w składzie tytułów (na przykład przeniesienia) czy — potocznie rozumianą — czytelnością ${ }^{23}$. (Ilustracje 14-16).

${ }^{23}$ Należy rozróżniać dwa pojęcia, które — niestety — w języku polskim nie mają osobnych określeń, przez co dochodzi do nieporozumień, nie tylko w tłumaczeniach. Czytelność (ang. legibility) to „łatwość i dokładność percepcji form znaków oraz wyrazów z nich zbudowanych”; inaczej — rozpoznawalność poszczególnych glifów. Łatwość czytania (ang. readability) to z kolei „miara tego, na ile dany tekst dostarcza łatwej i przyjemnej lektury", inaczej — komfort przyswajania tekstu. Por. J. Felici, Kompletny przewodnik po typografii. Zasady doskonatego składania tekstu, Gdańsk 2006, s. 332, 342. Terminy legibility i readability definiowane są również jako: „odróżnialność pojedynczego znaku pisma i łatwość zidentyfikowania go” oraz „stopień łatwości czytania złożonego tekstu, zrozumienia jego znaczenia i przesłania w określonej sytuacji”. Por. J. Mrowczyk, Niewielki słownik typograficzny, Gdańsk 2008, s. 53. Jako czynniki wpływające na jakość readability przyjmuje się między innymi: rodzaj składu, długość wiersza, tracking, kompozycja, oświetlenie, kontrast, stosowanie zasad składu i gramatyki, w końcu cech fizycznych nośnika komunikatu; do poprawienia jakości readability służy również styl języka, który powinien być zgodny z przeznaczeniem komunikatu i dostosowany do możliwości percepcyjnych odbiorcy (w tym jego osobowości, motywacji i intencji, warunków lektury). „Doświadczenie czytania” to między innymi komfort przyswajania tekstu (ang. readability), który musi być za każdym razem zdefiniowany przez zespół pracujący nad projektem (nie tylko projektanta, ale redaktora i wydawcę) i finalnie zagwarantowany czytelnikowi. 


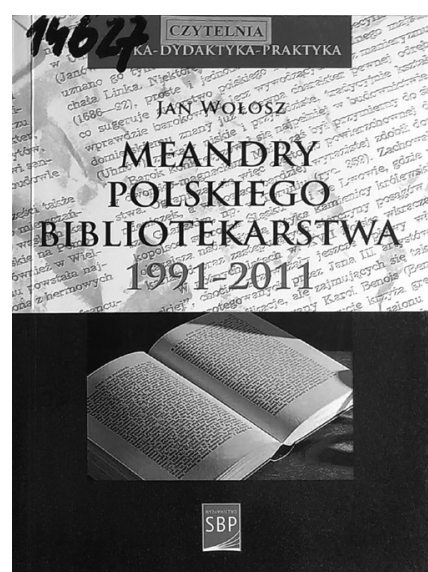

Ilustracja 14. J. Wołosz, Meandry polskiego

bibliotekarstwa 1991-2011, Warszawa 2012 (przednia strona okładki)

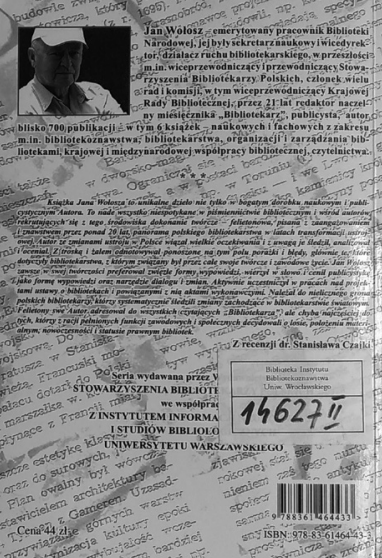

Ilustracja 15. J. Wołosz, Meandry polskiego bibliotekarstwa 1991-2011, Warszawa 2012

(tylnia strona okładki)

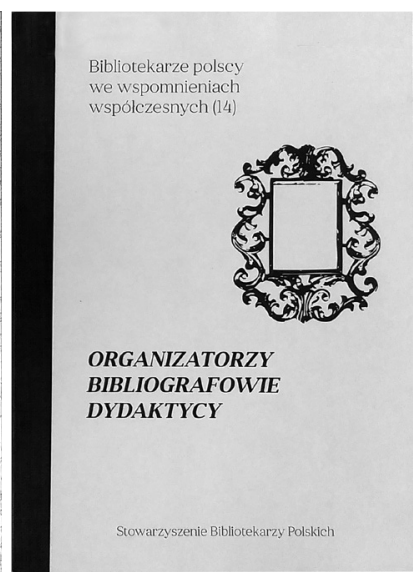

Ilustracja 16. Organizatorzy, bibliografowie, dydaktycy, Warszawa 2015

Od strony formalnej, takie kwestie, jak kompozycja, kolorystyka, jakość artystyczna i techniczna ilustracji, zastosowane kroje pisma, druk i jakość techniczna oprawy również pozostawiają wiele do życzenia. Należy podkreślić, że tak zwana forma graficzna, pojmowana potocznie jako „wartości estetyczne”, jest także determinantem użyteczności komunikatu wizualnego, ponieważ wszystkie jego elementy wpływają na jakość percepcji $\mathrm{i}$ - w efekcie — na zrozumienie sensu przekazu umieszczonego na okładce ${ }^{24}$. $Z$ tego też powodu forma i funkcja muszą intencjonalnie zawsze tworzyć jedność. Kwestie te doskonale tłumaczy Władysław Strzemiński we wstępie do Teorii widzenia:

[...] widzenie — to nie tylko bierny odbiór doznań wzrokowych. Otrzymane doznania poddajemy analizie myślowej, konfrontujemy z odpowiadającymi im odcinkami rzeczywistości, wyjaśniamy sens powstałych stąd wzajemnych związków i przyczyn: jakie doznania i co mówią o obiektywnie istniejącym świecie. Istnieje więc nie tylko bierny, fizjologiczny odbiór doznań wzrokowych, lecz obok niego - czynna poznawcza praca naszego intelektu. Istnieje wzajemny wpływ myśli na widzenie i widzenia na myśl. Myśl stawia pytania, na które ma odpowiedzieć widzenie. Widzenie daje zasób materiału obserwacyjnego - i ten zasób ulega sprawdzeniu i uogólnieniu w procesie opracowania myślowego. Dzięki ciągłej korekturze myśli w stosunku do widzenia możemy coraz lepiej korzystać z otrzymanych doznań wzrokowych. Nie puszczamy ich mimo siebie, nie dajemy im przeminąć bezowocnie, gdyż poznajemy, co każde z nich oznacza i jakiemu odcinkowi rzeczywistości odpowiada ${ }^{25}$.

24 Por. z definicjami typografii Andrzeja Tomaszewskiego oraz Tomasza Bierkowskiego: A. Tomaszewski, Leksykon pism drukarskich, Warszawa 1996, s. 232; T. Bierkowski, O typografii, Gdańsk 2008, s. 9, 41, 65, 83.

25 W. Strzemiński, Teoria widzenia, Kraków 1974, s. 13. 


\section{Zakończenie}

Świat dynamicznie się zmienia. W Polsce w ciągu ostatnich 25 lat jakość publikacji pod względem typograficznym znacznie się poprawiła, dorównując standardom zachodnim. Na tym tle publikacje bibliologiczne prezentują się źle, nawiązując — pod względem zastosowanych rozwiązań graficznych, standardów druku i oprawy — do siermiężnych dla polskiej typografii i poligrafii lat 90 . XX wieku. Powlekanie okładek lakierem na wysoki połysk, niewyszukane rozwiązania introligatorskie, ograniczony i powtarzający się zakres stosowanych krojów pisma, korzystanie z fontów zawierających podstawowe błędy konstrukcyjne glifów, korzystanie z krojów nieumiejętnie stylizowanych, deformowanie fontów (tak zwane rozciąganie), niska jakość artystyczna, użytkowa lub techniczna ilustracji, niejednolity skład notek na czwartej stronie okładki należą do najczęściej powtarzających się błędów.

Nie są to oczywiście przywary książek wyłącznie bibliologicznych, lecz zdecydowanej większości polskich publikacji naukowych. Problem wydaje się bardzo istotny, ponieważ uderza w sens pracy badaczy. Niejednokrotnie doskonałe książki naukowe, będące owocem wieloletnich prac badawczych i ogromnego wysiłku autora, otrzymują szatę graficzną uwłaczającą ich godności. W dodatku zaprojektowane są w sposób, który nie tylko nie zachęca, ale wręcz utrudnia lekturę czytelnikowi produkcyjnemu ${ }^{26}$.

Pośród omawianych okładek publikacji bibliologicznych pojawiają się także dobre przykłady. Są one wprawdzie nieliczne, lecz wyraźnie pokazują, że uzyskanie wysokiej jakości komunikacyjnej okładek publikacji bibliologicznych jest możliwe. (Ilustracje 17-19)

Cechują je właściwe skojarzenia/konotacje, jednoznaczność, spójność treści i formy (tworzą komunikacyjną jedność), niesztampowość rozwiązań formalnych (kolor, kompozycja, kroje pisma, papier, format, kompozycja układu typograficznego), oryginalność — rozumiana jako rozróżnialność spośród innych naukowych opracowań.

26 T. Zbierski dzieli odbiorców (czytelników) na trzy grupy: odbiorca-czytelnik potencjalny, który potrzebuje książki; odbiorca-czytelnik konsumpcyjny, który jest zaspokojony otrzymaną książką; odbiorca-czytelnik produkcyjny, to naukowiec lub student, którzy stają się w ten sposób producentami w innym cyklu twórczym. Odbiorcą produkcyjnym jest także producent użytkujący książkę w dalszym procesie produkcyjnym, por. op. cit., s. 15. 


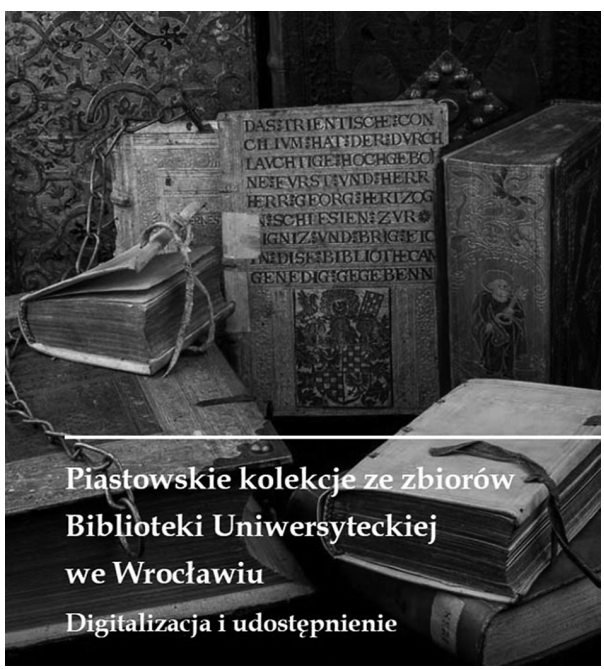

Ilustracja 17. Piastowskie kolekcje ze zbiorów Biblioteki Uniwersyteckiej we Wrocławiu. Digitalizacja i udostepnienie, Wrocław 2015

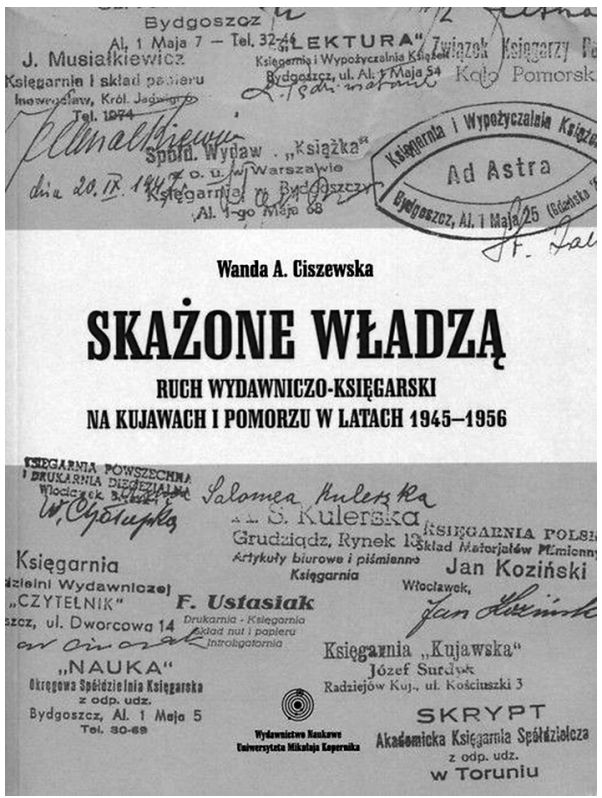

Ilustracja 18. W.A. Ciszewska, Skażone wtadza. Ruch wydawniczo-ksiegarski na Kujawach i Pomorzu w latach 1945-1956, Toruń 2015

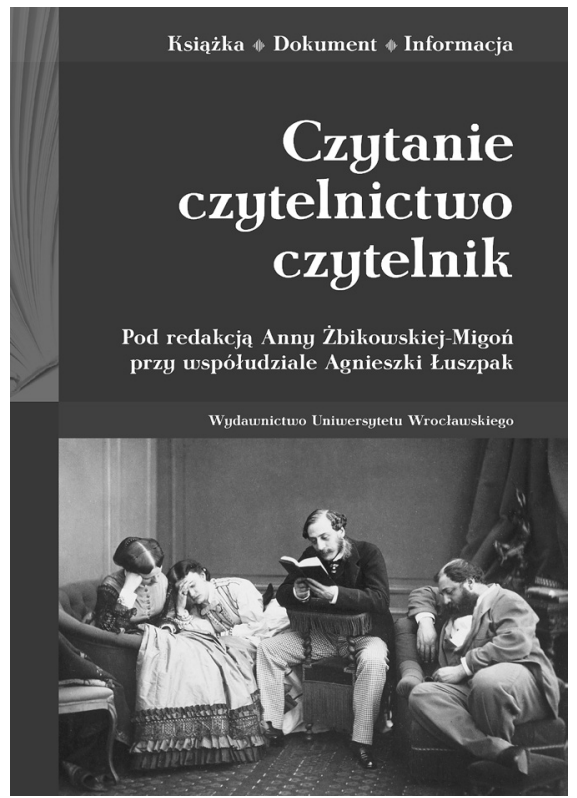

Ilustracja 19. Czytanie, czytelnictwo, czytelnik, Wrocław 2011

Celem niniejszego artykułu nie jest wytykanie błędów, lecz chęć zwrócenia uwagi na to, że forma zewnętrzna edycji z zakresu bibliologii i informatologii jest ważna, ponieważ sprzyja komunikacji i rozpowszechnianiu wiedzy. Wydawanie 
niskich jakościowo publikacji jest nie tylko nieużyteczne, lecz także aspołeczne i nieetyczne względem czytelników, publicznych pieniędzy, a także autorów. Ponadto nie mniejsze znaczenie mają kwestie wizerunkowe. Dobrze skonstruowane edycje świadczą o środowisku, z którego pochodzą. Problem jest niewątpliwie złożony i trudny, ale zmiana jest konieczna i, na co wskazują nieliczne przykłady edycji wzorowych, możliwa. Wbrew pozorom nie trzeba wiele. Wcale nie jest to, jak stereotypowo się sądzi, tylko kwestia finansów. To raczej design thinking, a więc projektowanie w oparciu o głębokie zrozumienie problemów i potrzeb użytkowników. Niezbędne jest więc na początku podniesienie świadomości autorów i wydawców, że za projektowanie książek naukowych powinni odpowiadać profesjonalnie kształceni projektanci, co niestety nie jest jeszcze w Polsce normą.

\section{Bibliografia}

Bielecki C., Głowa. Instrukcja użytkowania, Warszawa 2016.

Bierkowski T., Jak korzystać z wyników badań w tworzeniu komunikatów typograficznych, „Toruńskie Studia Bibliologiczne" 2015, nr 1 (14).

Bierkowski T., O typografii, Gdańsk 2008.

Breczko S., Książka naukowa - między środowiskiem akademickim a branża wydawniczq, „Nauka i Szkolnictwo Wyższe” 2016, nr 2 (48), http://pressto.amu.edu.pl/index.php/nsw/article/ view/7632 [dostęp: 31.05.2017].

Chi-Hang Tam K., Typograficzny pejzaż Wolfganga Weingarta, „,2+3D”2003, nr 6, http://www.2plus3d. $\mathrm{pl} /$ artykuly/typograficzny-pejzaz-wolfganga-weingarta/strona:1 [dostęp: 3.03.2017].

Chrzanowski A., Dotacje na podręczniki. Wydawcy akademiccy w Ministerstwie Nauki i Szkolnictwa Wyższego, „Biblioteka Analiz” 2008, nr 27.

Czubaj M., Kserówka, „Polityka” 2006, nr 7.

Dobrołęcki P., Najwięcej tytułów i niskie płace. Książka akademicka 2009/2010, „Biblioteka Analiz” 2010, nr 22.

Dobrołęcki P., Podręczniki bez dotacji, „Forum Książki” 2013, nr 1 (01) https://forumakademickie. pl/fk/2013/01/podreczniki-bez-dotacji/ [dostęp: 31.05.2017].

Dunin J., Oktadka i obwoluta jako komunikat. Wprowadzenie do problematyki, [w:] Sztuka ksiązki. Historia, teoria, praktyka, red. M. Komza, Wrocław 2003.

Dunin J., Okładki, obwoluty i wystawy książek w komunikacji literackiej, [w:] Pismo zmienia świat. Czytanie. Lektura. Czytelnictwo, Warszawa-Łódź 1998.

Felici J., Kompletny przewodnik po typografii. Zasady doskonatego sktadania tekstu, Gdańsk 2006.

Głombiowski K., Książka w procesie komunikacji społecznej, Wrocław-Warszawa-Kraków 1980.

Głombiowski K., Teoria i metodologia nauki o książce, Gdańsk 1985.

Gołębiewski Ł., Waszczyk P., Rynek ksiażki w Polsce 2015: wydawnictwa, Warszawa 2015.

Hojka B., Oktadka książkowa z perspektywy komunikacyjnej, [w:] W poszukiwaniu odpowiedniej formy. Rola wydawcy, typografa, artysty i technologii w pracy nad książka, red. M. Komza, Wrocław 2012.

Karwacki W., Mizeria czyli o książce akademickiej, „Notes Wydawniczy” 2001, nr 3-4.

Kieraciński P., Podręcznik w kryzysie, „Forum Książki” 2009, nr 1.

Kotarska-Lewandowska B., Komunikat graficzny w uczeniu się, [w:] Uczenie się i egzamin w oczach uczniów: XIII Konferencja Diagnostyki Edukacyjnej 5-7.10.2007, Łomża 2007. 
Mrowczyk J., Niewielki stownik typograficzny, Gdańsk 2008.

Norman D.A., The Design of Everyday Things, New York 2013.

Norman D.A., Wzornictwo i emocje, Warszawa 2015.

Repucho E., Typografia w przestrzeni cyfrowej jako przedmiot badań bibliologicznych, „Acta Poligraphica" 2016, nr 7.

Ruch wydawniczy w liczbach 2016. Książki, t. 63, Warszawa 2017, http://ksiegarnia.bn.org.pl/pdf/ Ruch\%20wydawniczy\%20w\%20liczbach\%2061_2015\%20ksiazki.pdf [dostęp: 31.05.2017].

Ruder E., Typography, Niederteufen 1977.

Saloni Z., Jak wydawatem skrypt, „Forum Akademickie” 2007, r. 14, nr 9.

Stopa-Pielesz E., Estetyka w typografii wobec postulatu czytelności, Kraków 2009.

Strzemiński W., Teoria widzenia, Kraków 1974.

Tomaszewski A., Leksykon pism drukarskich, Warszawa 1996.

Walewska J., Raport o stanie ksiażki akademickiej i naukowej, Warszawa 2001.

Walewska J., Uczelnia i spótka z o.o., „Notes Wydawniczy” 1999, nr 2.

Waszczyk P., Nie ma złych metod. Promocja podręczników akademickich, „Biblioteka Analiz” 2006, nr 22.

Zachrisson B., Studia nad czytelnością druku, Warszawa 1970.

Zbierski T., Semiotyka ksiązki, Wrocław 1978.

\section{What do covers say? About quality of visual communicates of Polish contemporary publications on bibliology and informatology}

Summary

The aim of the article is not only to point out at low quality of typography of contemporary scientific books published in Poland, but mainly to aware that it generates negative impact on communication value. In that context 400 books published in Poland by bibliologists in last 10 years were analyzed by authors of the article. The conclusions presented in the article were based on the analysis of the semantic quality of covers (semantic relations of text and image). The most typical and repetitive errors (e.g. neutrality, literalism and incompatibility) were shown and described. Last, but not least, it was proven by some of good examples, that working on and achieving the proper quality of communication in cover's design is possible, despite the costs. The only way to success is to understand the real needs of users and design thinking in books' design.

KEYWORDS: publishing, book design, typography, cover, visual communication, scientific book, bibliology, design thinking 